\title{
PENGARUH MICROBLOGGING EDMODO TERHADAP KEMANDIRIAN DAN HASIL BELAJAR PESERTA DIDIK PADA MATERI PENCEMARAN LINGKUNGAN
}

\author{
Rachmanita Prihana Rizki ${ }^{1}$, Sabar Nurohman ${ }^{2}$ \\ ${ }^{1,2}$ Pendidikan IPA, Universitas Negeri Yogyakarta, Indonesia \\ Corresponding author email: prihanarizki@gmail.com
}

\begin{abstract}
Submit: 18 Maret 2021
Accepted: 22 April 2021

Publish: 30 April 2021

Abstrak:

Penelitian ini bertujuan untuk mengetahui pengaruh Microblogging Edmodo terhadap kemandirian dan hasil belajar peserta didik kelas VII SMP N 1 Minggir pada materi pencemaran lingkungan. Jenis penelitian ini adalah quasy eksperimen dengan nonequivalent control group design. Populasi penelitian ini adalah seluruh kelas VII SMP N 1 Minggir sebanyak 7 kelas. Sampel ditentukan dengan teknik cluster random sampling didapatkan kelas VII A sebagai kelas eksperimen dengan pembelajaran menggunakan Edmodo dan kelas VII C sebagai kelas kontrol dengan pembelajaran menggunakan media tayang berupa LCD. Instrumen penelitian yang digunakan adalah (1) angket kemandirian belajar, (2) lembar observasi kemandirian, dan (3) soal kognitif. Uji hipotesis menggunakan independent sample t test dan MANOVA dilanjutkan perhitungan Cohen's effect. Hasil penelitian ini adalah (1) terdapat pengaruh penggunaan Edmodo terhadap kemandirian belajar peserta didik pada materi pencemaran lingkungan; (2) terdapat pengaruh penggunaan Edmodo terhadap hasil belajar peserta didik pada materi pencemaran lingkungan; dan (3) terdapat pengaruh penggunaan Edmodo terhadap kemandirian dan hasil belajar peserta didik secara simultan pada materi pencemaran lingkungan.
\end{abstract}

Kata kunci: Edmodo, hasil belajar, kemandirian belajar

\begin{abstract}
This research aims to know the influence of Microblogging Edmodo on self-reliance and the outcomes of learners class VII SMP N 1 Minggir on environmental pollution material. This type of research is Quasy experiment with nonequivalent control group Design. The population of this study is all class VII SMP N 1 Minggir as many as 4 classes. The sample was determined by cluster random sampling technique obtained class VII A as an experimental class with learning using Edmodo and class VII C as a control class with learning using a media display in the form of $L C D$. The research instruments used are (1) Learning Independence Questionnaire, (2) Self-reliance Observation sheet, and (3) cognitive problems. The hypothesis test uses the Independent sample T Test and The MANOVA continues the Calculation Of Cohen's effect. The result of this study is (1) an influence on the use of Edmodo on the independence of learning students in environmental pollution material; (2) there is an influence on the Use Of Edmodo on student learning outcomes on environmental pollution material; and (3) There is an influence on the use of Edmodo on self-reliance and students' learning outcomes on the topic of environmental pollution simultaneosly.
\end{abstract}

Keywords: Edmodo, learning outcomes, learning independence 


\section{Physics and Science Education Journal (PSEJ) \\ Volume 1 Nomor 1, April 2021}

\section{Pendahuluan}

Pembelajaran adalah proses komunikasi dua arah (adanya timbal balik) berupa penyampaian pesan antara guru dan peserta didik. Pembelajaran akan mencapai hasil yang maksimal apabila semua aspek pembelajaran disiapkan dengan baik, tidak hanya dari kesiapan guru dan peserta didik, namun juga terkait bahan ajar dan media yang digunakan. Adanya bahan ajar dan media yang menarik bagi peserta didik akan berdampak pada minat serta kemandirian belajar peserta didik pada pelajaran IPA.

Kurangnya kemandirian belajar peserta didik dalam pembelajaran IPA berdampak pada hasil belajar peserta didik yang juga rendah, dibuktikan dengan nilai ulangan akhir semester 1 IPA kelas 7 memiliki rata-rata nilai 53,68 dan banyak peserta didik yang berada pada rentang nilai 50,00-59,99. Kategori nilai diatas 70,00 hanya ada 16 anak dari 227 peserta didik kelas 7. Tentunya media pembelajaran dapat dioptimalkan disini, dengan adanya media pembelajaran yang menarik perhatian peserta didik serta dapat memandirikan peserta didik agar fokus ketika pembelajaran dan mendapatkan hasil yang baik

Guru kurang memanfaatkan fasilitas yang ada sebagai media pembelajaran yang dapat menarik perhatian peserta didik dalam pempelajaran. Peserta didik cenderung malas mendengarkan penjelasan dari guru dan memilih berbicara dengan teman sebangkunya. Hal ini menunjukan bahwa kemandirian belajar terhadap mata pelajaran IPA di SMP N 1 Minggir masih rendah.

Peserta didik di SMP N 1 Minggir diperbolehkan untuk membawa smartphone namun hanya pada waktu tertentu dan hanya digunakan pada mata pelajaran tertentu. Diperbolehkannya peserta didik membawa smartphone bukan berarti penggunaannya bersifat bebas tanpa syarat, namun gadget hanya diperbolehkan digunakan saat sebelum pembelajaran, istirahat maupun selepas bel pulang sekolah. Gadget dapat pula digunakan untuk mengerjakan soal namun atas perijinan guru yang sedang mengajar. Sayangnya gadget yang dimiliki peserta didik sebagaian besar hanya digunakan untuk bermain game dam bersosial media serta belum memiliki satu pun aplikasi yang mendukung pembelajaran.

SMP N 1 Minggir juga memiliki Laboratorium Komputer yang berjumlah 2 ruangan. 1 Laboratorium Komputer di SMP N 1 Minggir jarang sekali digunakan karena biasanya digunakan hanya saat ujian kelas 9 saja dan laboratorium yang satunya digunakan untuk pelajaran TIK. Dengan tidak terpakainya Laboratorium Komputer maka tidak menutup kemungkinan pembeajaran IPA dapat memanfaatkan media berbasis teknologi informasi dan komunikasi. Oleh sebab itu, Laboratorium Komputer yang ada di SMP N 1 Minggir bisa dimanfaatkan untuk pembelajaran IPA berbasis Edmodo

Edmodo adalah salah satu media pembelajaran yang dikembangkan oleh Nic Borg dan Jeff O' Hara. Rismayanti (2012:1) menjelaskan bahwa Edmodo adalah platform (program) media social yang sering digunakan sebagai facebook untuk sekolah, hal ini dikarenakan tampilannya yang mirip aplikasi facebook.. Peserta didik tidak dapat berhubungan dengan orang asing karena pada ruang Edmodo tidak ada yang dapat masuk kecuali menggunakan undangan. Hal ini menjadi kelebihan Edmodo dimana guru berada dalam platform yang sama dengan peserta didik, maka guru dapat mengawasi interaksi peserta didik, berkolabirasi langsung, dan saling berbagi file dalam banyak format. (Maymadya,2017:02).

Edmodo sebagai salah satu media pembelajaran berbasis E-learning yaitu suatu pembelajaran yang memanfaatkan teknologi elektronik dan ditunjang pula dengan jaringan computer dan atau internet (Rusman dkk. 2012: 265) E-learning dalam bidang pendidikan digunakan sebagai tambahan terhadap proses belajar secara tatap muka maupun alternatif saat berhalangan hadir untuk melaksanakan pembelajaran secara tatap muka. Guru dapat memanfaatkan media pembelajaran Edmodo berbasis Elearning untuk tetap bisa menjalankan aktivitas pembelajaran walaupun tidak bisa bertatap muka dalam kelas.

Jurnal yang menyebutkan penelitian menggunakan media pembelajaran Edmodo pada peserta didik SMP dilakukan oleh Sudibyo dan Wasis(2013) yang meneliti tentang penggunaan media pembelajaran berbasis Edmodo Blog Education terhadap kemandirian dan hasil belajar peserta didik SMP N 4 Surabaya kelas VIII materi Alat Optik yang terbukti ada peningkatan hasil belajar peserta didik dan adanya respon yang positif dari angket kemandirian belajar. Berdasarkan penelitian tersebut serta uraian permasalahan yang telah penulis kemukakan, penulis juga terinsprirasi untuk melakukan penelitian mengenai penerapan media sosial Edmodo pada peserta didik SMP. Tujuan penelitian ini adalah untuk mengethaui pengaruh sosial media Edmodo sebagai basis E-Learning terhadap kemandirian dan hasil belajar peserta didik mata pelajaran IPA pada materi Pencemaran Lingkungan. 


\section{Metode Penelitian}

\section{Jenis Penelitian}

Penelitian ini menggunakan pendekatan kuantitaif. Bentuk penelitian ini adalah quasi experiment. Menurut Sugiyono (2018) bahwa metode penelitian eksperimen merupakan "metode penelitian yang digunakan untuk mencari pengaruh treatment (perlakuan) tertentu.

\section{Waktu dan Tempat Penelitian} 2019/2020.

Penelitian ini dilakukan pada bulan Januari-Maret 2020 di SMP N 1 Minggir pada tahun pelajaran

\section{Populasi dan Sampel Penelitian}

Populasi penelitian ini adalah seluruh kelas VII SMP N 1 Minggir tahun pelajaran 2019/2020 berjumlah 227 peserta didik. Pengambilan sampel dilakukan secara cluster random sampling yaitu sampel ditentukan secara acak berdasarkan kelas. Penentuan kelas dengan menggunakan teknik ini harus memenuhi syarat normal dan homogen artinya semua anggota kelompok tersebut harus memiliki karakteristik atau kemampuan awal yang sama, sehingga sampel yang terpilih dapat mewakili populasi peserta didik

\section{Prosedur}

Desain penelitian yang digunakan pada penelitian ini secara umum rancangan yang digunakan pada penelitian ini ada 2 macam yaitu Non- equivalent Control Group Design digunakan untuk mengukur Hasil Belajar dan Posttest only control group Design untuk mengukur Kemandirian Belajar.

Tabel 1. Desain penelitian nonequivalent control group pretest-posttest design untuk pengambilan data Hasil Belajar

\begin{tabular}{ccc}
\hline $\mathrm{O}_{1}$ & $\mathrm{X}_{1}$ & $\mathrm{O}_{2}$ \\
\hline $\mathrm{O}_{3}$ & $\mathrm{X}_{2}$ & $\mathrm{O}_{4}$ \\
\hline \multicolumn{3}{c}{ Sumber: Sugiyono (2018) }
\end{tabular}

Tabel 2. Desain Penelitian nonequivalent control group posttest-only design untuk pengambilan data Kemandirian Belajar.

\begin{tabular}{cc}
\hline $\mathrm{X}_{1}$ & $\mathrm{O}_{2}$ \\
\hline $\mathrm{X}_{2}$ & $\mathrm{O}_{4}$ \\
\hline & Sumber: Privitera, G.J. \& Delzell, L.A. (2019)
\end{tabular}

Keterangan:

$\mathrm{O}_{1}=$ pengukuran kemampuan awal kelompok eksperimen

$\mathrm{O}_{2}=$ pengukuran kemampuan akhir kelompok eksperimen

$\mathrm{X}_{1}=$ penggunaan Microblogging Edmodo pada kelompok eksperimen

$\mathrm{X}_{2}=$ pendekatan saintifik pada kelompok kontrol

$\mathrm{O}_{3}=$ pengukuran kemampuan awal kelompok kontrol

$\mathrm{O}_{4}=$ pengukuran kemampuan akhir kelompok kontrol.

\section{Intrumen Penelitian}

Instrument yang digunakan untuk mengumpulkan data yaitu soal pretest dan posttest digunakan untuk melihat ada tidaknya pengaruh microblogging Edmodo terhadap hasil belajar peserta didik, angket dan lembar observasi untuk melihat ada tidaknya pengaruh microblogging Edmodo terhadap kemandirian belajar dan lembar observasi keterlaksanaan pembelajaran. 


\section{Teknik Analisis Data}

Teknik analisis data yang digunakan dalam penelitian ini meliputi uji validitas, reabilitas soal, uji prasyarat hipotesis (normalitas dan homogenitas), gain ternormalisasi, uji hipotesis (Independent sample ttest dan Manova), dan Effect Size. Uji Independent Sample T-test adalah uji komparatif atau uji beda untuk mengetahui adakah perbedaan mean atau rerata yang bermakna antara 2 kelompok kelas yang dalam penelitian ini yaitu perbedaan antara kelas eksperimen yang menggunakan media pembelajaran Edmodo serta kelas kontrol yang tidak menggunakan media Edmodo. Uji M merupakan suatu teknik statistik yang digunakan dalam pengujian terhadap perbedaan antar rerata dari 2 atau lebih suatu populasi (sampel penelitian) dengan dua atau lebih variabel terikat dependent. Effect size digunakan untuk mengetahui Besarrnya pengaruh pembelajaran IPA menggunakan media pembelajaran Edmodo terhadap Kemandirian dan Hasil Belajar Peserta Didik. Besarnya pengaruh effect size berdasarkan kategori berikut:

Tabel 3. Kriteria Cohen's effect size

\begin{tabular}{cc}
\hline Skala & Kriteria \\
\hline $\mathrm{d}>1,00$ & Sangat besar $($ Strong effect $)$ \\
\hline $0,51 \leq \mathrm{d} \leq 1,00$ & Besar $($ Moderate effect $)$ \\
\hline $0,21 \leq \mathrm{d} \leq 0,50$ & Sedang $($ modest effect $)$ \\
\hline $0<\mathrm{X} \leq 0,20$ & Kecil $($ weak effect $)$ \\
\hline & Sumber: (Cohen, et al,2007:617)
\end{tabular}

Teknik analisis data untuk mengetahui keterlaksanaan pembelajaran pada kelas eksperimen maupun kelas kontrol yaitu menggunakan analisis persentase keterlaksanaan pembelajaran dari hasil observasi kegiatan guru dan peserta didik.

\section{Hasil Penelitian dan Pembahasan}

\section{Keterlaksanaan pembelajaran IPA}

Keterlaksanaan proses pembelajaran dihitung melalui persentase kegiatan yang terlaksana. Lembar keterlaksanaan diisi oleh dua observer mulai dari pertemuan pertama hingga pertemuan ketiga. Hasil analisis keterlaksanaan pembelajaran disajikan pada Tabel 8.

Tabel 4. Hasil Perhitungan Skor Keterlaksanaan Pembelajaran

\begin{tabular}{lcccccc}
\hline & \multicolumn{3}{c}{ Kelas Eksperimen } & \multicolumn{3}{c}{ Kelas Kontrol } \\
\hline Pertemuan & 1 & 2 & 3 & 1 & 2 & 3 \\
\hline Skor Keterlaksanaan & & & & & & \\
& 25 & 26 & 21 & 22 & 23 & 20 \\
\hline Skor Total & 28 & 28 & 28 & 26 & 26 & 24 \\
\hline Persentase (\%) & 89.3 & 92.9 & 75.0 & 84.6 & 88.5 & 83.3 \\
\hline Rata-rata (\%) & 85.7 & & & 85.5 & \\
\hline
\end{tabular}

Berdasarkan Tabel 4, rata-rata persentase keterlaksanaan kelas eksperimen lebih tinggi daripada kelas kontrol. Namun, baik kelas eksperimen maupun kontrol memiliki persentase yang tinggiyaitu 85,7 (kelas eksperimen) dan 85,5 (kelas kontrol). Ini menunjukkan bahwa keterlaksanaan pembelajaran berada pada kriteria sangat baik. . Persentase pembelajaran tidak mencapai nilai 100\% dikarenakan adanya satu ataupun dua langkah pembelajaran yang tidak terlaksana baik di kelas Eksperimen maupun Kontrol. Namun secara keseluruhan pembelajaran dapat terlaksana dengan baik dan optimal.

\section{Pengaruh Microblogging Edmodo Terhadap Kemandirian Belajar Peserta Didik}


Adanya pengaruh Microblogging Edmodo terhadap kemandirian belajar peserta didik diperoleh dari hasil uji Independent Sample T-Test yang hasilnya ada perbedaan antara kelas eksperimen dan kelas kontrol. Adanya perbedaan tersebut mengindikasikan adanya pengaruh Microblogging Edmodo terhadap kemandirian belajar yang besarnya pengaruh dapat diketahui menggunaan perhitungan effect size yang hasilnya adalah 0,55 dengan kategori besar. Namun dalam pengambilan keputusan ini terdapat suatu keterbatasan karena peneliti tidak mengukur keterampilan awal kemandirian belajar peserta didik sehingga rerata nilai yang dipakai untuk perhitungan effect size adalah rerata nilai observasi setelah adanya perlakuan.

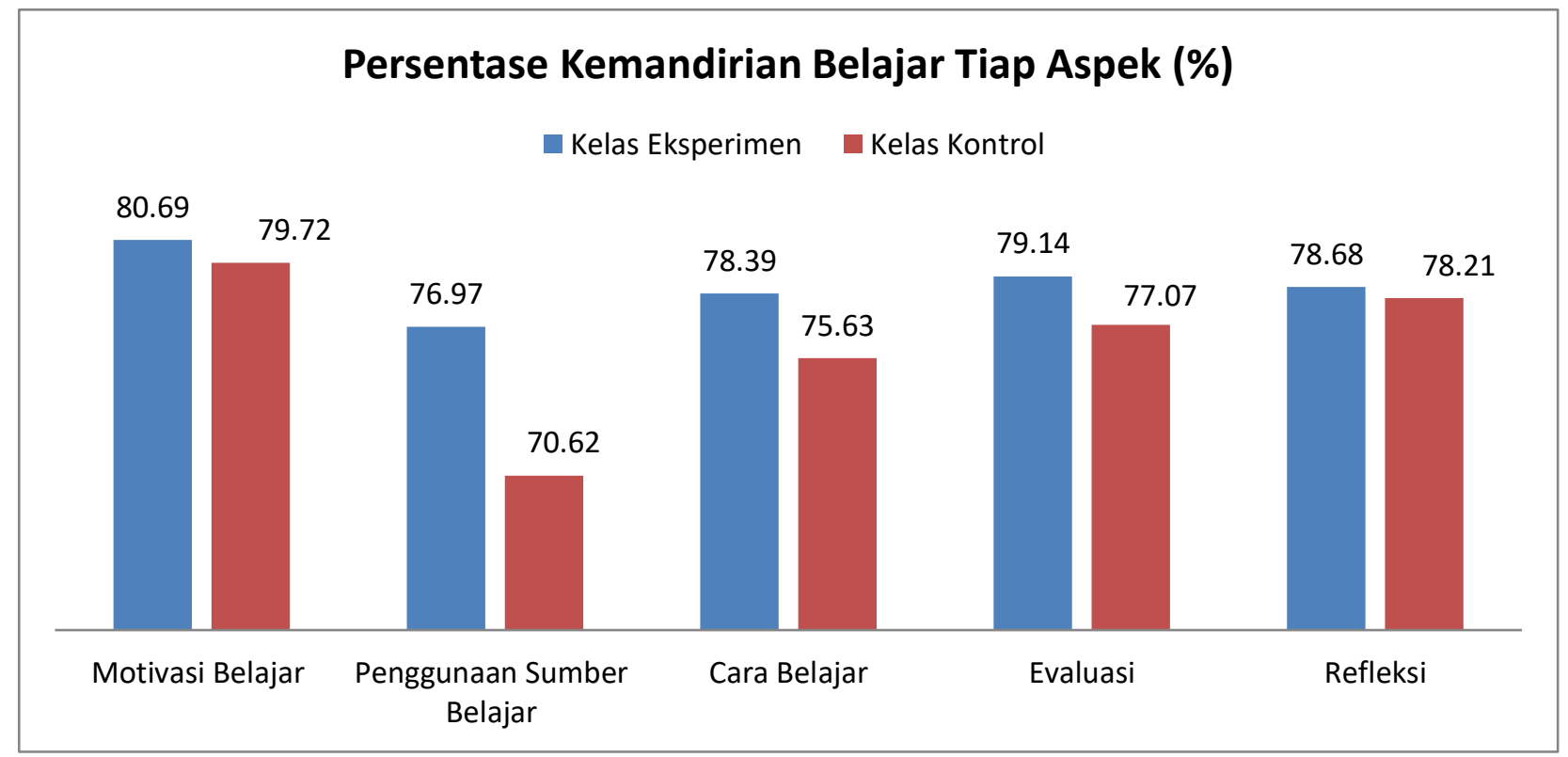

Gambar 1. Diagram Perbandiang Setiap Aspek Kemandirian Belajar Kelas Eksperimen dan Kelas Kontrol

Berdasarkan Gambar 2 ,aspek motivasu belajar peserta didik kelas eksperimen lebih tinggi dibandingkan kelas kontrol. Ini menunjukkan bahwa Edmodo memiliki dampak yang positif terhadap kemandirian belajar peserta didik. Peserta didik antusias dalam pembelajaran menggunakan Edmodo karena tampilannya yang menarik dan membuat peserta didik tidak cepat bosan Apabila ditinjau dari rata-rata kemandirian belajar, kelas eksperimen memiliki nilai rata-rata yang lebih tinggi dibandingkan kelas kontrol. Hal tersebut menunjukkan bahwa penggunaan Microblogging Edmodo pada saat pembelajaran memberikan pengaruh lebih terhadap kemndirian belajar peserta didik dibandinng pembelajaran yang tidak menggunakan Edmodo.

Berdasarkan hasil yang sudah dideskripsikan pada paragraf diatas, dapat dikatakan bahwa pembelajaran dengan menggunakan media pembelajaran Edmodo memiliki pengaruh terhadap kemandirian belajar peserta didik. Hal ini sesuai dengan pernyataan Virgiana (2015: 32) bahwa penggunaan media pembelajaran yang digunakan juga dapat mendukung dalam peningkatan kemandirian belajar. Hal ini sejalan dengan penelitian (Oktavera, 2015: 96), yang menyatakan bahwa adanya media pembelajaran membantu peserta didik dalam meningkatkan kemandirian belajar sebagai sarana yang mendukung dalam kegiatan belajar mandiri sehingga peran guru dapat berubah hanya sebagai fasilitator.

\section{Pengaruh Microblogging Edmodo terhadap Hasil Belajar Peserta Didik}

Adanya pengaruh Microblogging Edmodo terhadap hasil belajar peserta didik diperoleh dari hasil uji Independent Sample T-Test yang hasilnya ada perbedaan antara kelas eksperimen dan kelas kontrol. Adanya perbedaan tersebut mengindikasikan adanya pengaruh Microblogging Edmodo terhadap hasil belajar yang besarnya pengaruh dapat diketahui menggunaan perhitungan effect size yang hasilnya adalah 0,77 dengan kategori besar. 


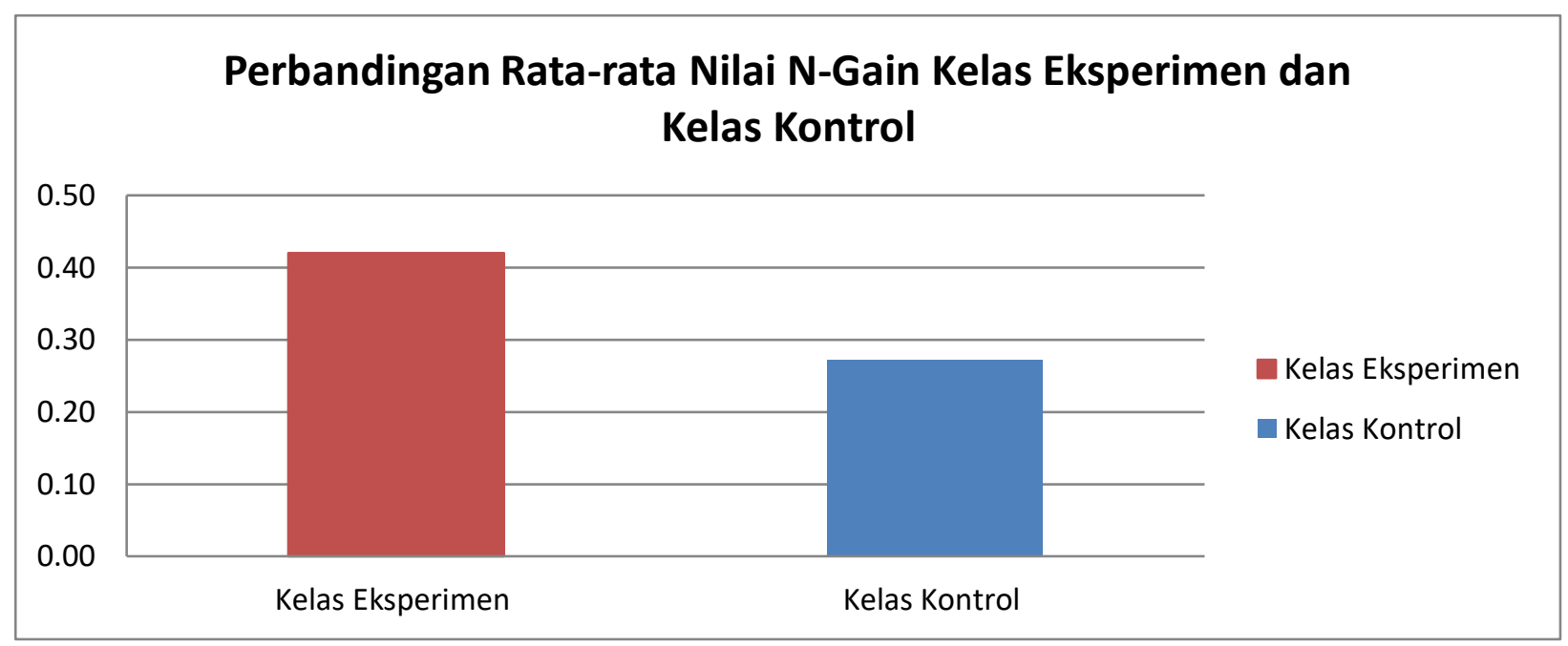

Gambar 1. Diagram Perbandingan Rata-rata Nilai N-Gain Hasil Belajar Kelas Eksperimen dan Kelas Kontrol

Berdasarkan pendapat dari Hake (1999:101) skoe N-Gain kelas eksperimen tergolong sedang yaitu berada antara rentang 0,3 hingga 0,7 sedangkan skor gain ternormalisasi kelas kontrol tergolong rendah karena berada dibawah 0,3 . Hal ini menunjukkan adanya suatu perbedaan hasil antara kelas eksperimen yang menggunakan media Edmodo dengan kelas kontrol yang tidak menggunakan media Edmod.

Menurut Wasliman dalam Susanto (2015:12) dijelaskan bahwa salah satu faktor yang yang mempengaruhi hasil belajar adalah adanya minat dan perhatian serta motivasi. Sedangkan faktor tersebut dipengaruhi oleh adanya media pembelajaran. Sebagaimana dikemukakan oleh Sanaky (2013:6) yaitu media pembelajaran memberikan manfaat diantaranya memberikan suasana belajar yang menyenangkan dan menarik peserta didik untuk belajar. Meningkatkan kemandirian belajar dan memudahkan peserta didik dalam memahami materi. Selain itu, fungsi dari media pembelajaran adalah salah satunya fungsi atensi yaitu menarik perhatian peserta didik untuk berkonsentrasi kepada isi pembelajaran. Berdasarkan pernyataan para ahli tersebut dapat mendukung pernyataan bahwa melalui penerapan pembelajaran Online dengan menggunakan media pembelajaran Edmodo memang berpengaruh terhadap hasil belajar peserta didik.

\section{Pengaruh Microblogging Edmodo terhadap Kemandirian dan Hasil Belajar Peserta Didik}

Adanya pengaruh penerapan sistem pembelajaran online dengan menggunakan media pembelajaran Edmodo terhadap kemandirian dan hasil belajar peserta didik ialah sedang. Hal ini dapat dilihat dari perhitungan Effect size yang menunjukkan bahwa pengaruh penelitian ini pada variabel kemandirian belajar dan hasil belajar berturut-turut adalah 0,55 dan 0,77 . Jika dirata-rata nilai kedua Effect size tersebut dalam kategori sedang.

Adanya pengaruh Microblogging Edmodo dalam pembelajaran IPA terhadap kemandirian belajar dan hasil belajar didukung adanya media pembelajaran yang membantu proses belajar mengajar di kelas. Hal ini sejalan dengan penelitian (Oktavera, 2015), yang menyatakan bahwa adanya media pembelajaran membantu peserta didik dalam meningkatkan kemandirian belajar sebagai sarana yang mendukung dalam kegiatan belajar mandiri sehingga peran guru dapat berubah hanya sebagai fasilitator.

Faktor lain yang dapat mempengaruhi hasil belajar menurut Susanto (2013:17) ialah model penyajian materi pelajaran. Keberhasilan peserta didik dalam belajar tergantung pula pada model penyajian materi. Model penyajian materi yang menyenangkan, tidak membosankan, menarik dan mudah dimengerti oleh para peserta didik tentunya bepengaruh positif terhadap keberhasilan belajar. Hal ini mendukung alas an diterapkannya pembelajaran Online dengan menggunakan Edmodo. Media Edmodo memberikan suatu pengalaman belajar yang menyenangkan dengan tampilan yang menarik sehingga peserta didik akan mudah dalam mempelajari suatu materi pelajaran. 


\section{Simpulan}

Berdasarkan hasil penelitian dan pembahasan, peneliti dapat membuat simpulan sebagai berikut (1) Penggunaan Microblogging Edmodo berpengaruh secara signifikan terhadap Kemandirian Belajar peserta didik pada pokok bahasan pencemaran lingkungan yang termasuk dalam kategori besar. (2) Penggunaan Microblogging Edmodo berpengaruh secara signifikan terhadap Hasil Belajar peserta didik pada pokok bahasan pencemaran lingkungan yang termasuk dalam kategori besar.(3) Penggunaan Microblogging Edmodo berpengaruh secara signifikan terhadap Kemandirian Belajar dan Hasil Belajar peserta didik secara simultan pada pokok bahasan pencemaran lingkungan. Berdasarkan hasil penelitian, pada penelitian ini memiliki beberapa saran sebagai berikut.(1) Bagi guru penggunaan media Edmodo pada pembelajaran IPA dapat dilakukan dengan lebih memanfaatkan fitur quiz dan link. Kedua fitur ini berperan baik dalam menunjang kemandirian peserta didik dalam pembelajaran. (2)Bagi peneliti selanjutnya, hendaknya dalam melakukan penelitian juga dipertimbangkan seara matang mengenai materi yang sesuai dengan media pembelajaran yang digunakan serta tujuan dari pembelajaran yang ingin dicapai, (3) Bagi sekolah penelitian ini diharapkan dapat digunakan sebagai alternative pembelajaran yang dapat meningkatkan kualitas pembelajaran di sekolah.

\section{Referensi}

Cohen, et al. (2007). Metode Penelitian dalam Pendidikan. New York. Routledge. 657 Hal

Maymadya, L. (2017). Pengembangan Tutorial Edmodo Untuk Tenaga Pengajar. Jurnal Kajian Teknologi Vol.2 No. 1.

Oktavera, S. (2015). Pengaruh Media Pembelajaran dan Kemandirian Belajar Terhadap Hasil Belajar IPA Peserta didik Kelas IV Sekolah Dasar. Jurnal Pendidikan Dasar, 6 (2), 327-338

Privitera, G.J. \& Delzell, L.A. (2019). Quasi-Experimental and Single-Case Experimental Design Chapter Thirteen. California: SAGE Publication Inc

Rusman, K \& Riyana. (2012). Pembelajaran Berbasis Teknologi Informasi dan Komunikasi : Rajagrafindo Persada

Rismayanti, A. (2013). Mengenal Lebih Dekat Edmodo sebagai media E-Learning dan Kolaborasi. Bandung: Alfabeta

Sanaky, H (2013). Media Pembelajaran interaktif-Inovatif. Yogyakarta: Kaukaba Dipantara.

Sudibyo \& Wasis (2013) Penggunaan Media Pembelajaran Fisika dengan E-Learning berbasis Edmodo Blog Education pada materi Alat Optik untuk meningkatkan respons dan hasil belajar peserta didik di SMP Negeri 4 Surabaya. Journal FMIPA. Universitas Negeri Surabaya

Sugiyono. (2018). Metodelogi Penelitian Kuantitatif, Kualitatif Dan R\&D. Bandung: Alfabeta

Susanto, A. (2013). Teori Belajar dan Pembelajaran di Sekolah Dasar. Jakarta: Prenadamedia Group. 